\title{
突発性前庭機能低下による症状とその恢復過程について
}

\author{
徳増 厚二・田代 直樹・五島 一吉・八尾 和雄 \\ Symptoms and their Time Course in the Patient of Acute
Peripheral Vestibular Lesion
}

Kohji Tokumasu, Naoki Tashiro, Kazuyoshi Goto and Kazuo Yao

(Kitasato University)

Severe vertigo, violent spontaneous nystagmus and body ataxia usually appears when the peripheral vestibular organ is rapidly damaged unilaterally. These symptoms due to acute vestibular asymmetry may gradually be eliminated with different time courses depending upon the symptom. Spontaneous recovery from the eye and body disequilibria is considered to occur by way of the central compensation mechanism.

Training therapy of repeated vestibular stimulation was administered to four cases of acute peripheral vestibular disturbance with the expectation of acceleration of the patients gaining the central compensation. The rationale for this therapy lies in the fact that the post-rotatory nystagmus, which is assumed to be a sign produced by transient vestibular asymmetry, be can suppressed by repeated rotatory stimulations.

The following results were obtained after a relatively long clinical observation.

All pathological symptoms disappeared 7 weeks after the onset in a case of a 5year-old boy with serious labyrinthitis.

In cases of 60-year-old and 74-year-old patients with vestibular neuronitis, some of the symptoms, especially discoordination between the head and the eyes, persisted for a long time until they were finally eliminated. In both cases, dizzy sensation provoked by head movement and positioning nystagmus to the intact side appeared sporadically until one year and seven months after the onset whenever the patients felt fatigued in their daily lives. Marked body ataxia without visual fixation persisted for a long time in a case of streptomycin intoxication, although it was slightly decreased 2 years and 5 months after the onset.

The authors hope to confirm the effectiveness of this training therapy for patients the with peripheral vestibular disturbance in further studies.

$$
\text { は じめに }
$$

一側内耳破壊動物の観察は1824年鳩についての Flourens の実験以来多くの研究者によって引き つがれている．平衡障害の中枢性代償の考えは1883年の有名な Bechterew 眼振がきっかけとなっ 
て進展した. 1930年には Fischerや Magnus and De Kleijn らによりすべての咉椎動物で一側内 耳破壞のもたらす症状は基本的には同じであって，いづれも経時的に次第に軽減するが，その時間 的変化は動物により異ると報告された（Schaeffer et al. 1974）.

また正常の動物やヒトで前庭刺激によって誘発される感覚や眼振反応が，視覚や他の感覚と矛盾 する場合, 繰り返しの前庭刺激によって前庭性誘発反応は次第に減弱するといわれている (Collins. 1974)。したがって反復前庭刺激が前庭障害の中枢性代償獲得にどの様な影響があるか興味ある問 題である.

我々はヒトの急性末梢性前庭障害例に, 症状の恢復を促進するととを期待して積極的に頭振り運 動を負荷し，その経過を観察し，あわせてめまい平衡障害の恢復過程に考察を加えた.

\section{研究方法, 研究対象}

漿液性内耳炎 1 例，前庭神経炎 2 例，ストレ プトマイシン中毒 1 例, 計 4 例の末梢性前庭障 害例について最長 3 年 7 月の期間にわたって経 過を観察した。いづれも安静時のめまいが消失 した時点から毎日一点注視で頭部を左右に10回 ふる動作と閉眼足踏みの練習を実施させた.

〔症例 1]No. 376596 才男

感冒に罹患し発熱とともに左耳鼓膜が発赤し ていたため近医で鼓膜切開を受けた。そのの後激 しいめまいと嘔吐．歩行障害が出現した，発症 2 日目に来院した時の検査では左鼓膜には切開 痕, 鼓膜の発赤, 僅かの耳漏がみられた。聴力検 査では会話音域の平均聴力 $45 \mathrm{~dB}$ の混合難聴が あり，平衡機能検査ではロンベルグ陽性，閉眼 足踏みでは 4 歩で転倒し，注視時には眼振は既 にないが，フレンッェル眼鏡下で $1.3 \mathrm{HZ}$ の左 向水平回旋混合性眼振がみられた。 その後発症 10日目には30歩の閉眼足ぶみが可能となり 7 週 目にはめまいおよびすべての平衡障害と聴力障 害が消失した。聑漏から Proprionibacterium 菌が検出されたためセフアロスポリン系抗生物 質を投与し同時に頭ふり運動訓練をおてない完 全治療をみた。本例は中耳炎の内耳波及による 漿液性内耳炎之診断された。

\section{〔症例 2〕No. 284605 60才男 眼科医}

集会にてビールを飲んでいたら急に頭の鳴る ような感じとともにめまい，嘔吐が出現した， めまいは始め目の前の机が傾く感じがおこりそ れから周囲が右より左へ流れた。血圧は150/90
であったがその後128/70に落ちついた．就床し めまいがようやく軽減した 5 日目に歩けるよう になってから歩行時前方の景色が踊って見元 た.

変形性関節炎, 喘息, 薬疹の既往症がありア レルギー体質であった。なおめまい発症前から 感冒に罹患していた.

発症後 3 週目に来院. 聴力検査では年令変化 と考元られる両側軽度の高音難聴をみとめた。 平衡機能検査ではロンベルグ陽性, 足踏検査に て $45^{\circ}$ 右方への偏倚とふらつき, 温度検査では 右高度の迷路機能低下がみとめられた。しかし 注視眼振, フレンツェル眼鏡下での自発眼振, 頭位・頭位变換眼振はなかった。

その後体が疲労すると動摇感のめまいが強く なり左向きの微細な水平性頭位眼振, 足踏み検 査での右向き偏倚が出没した。発症 9 月目の遮 眼暗算下の左向き水平性眼振の ENG 記録と振 子様 回転検査での左向き眼振方向優位性（左 DP）を図 1 亿示す.

足踏み検査での右方偏倚が時々みとめられ た。、ン検査での閉眼直立持続時間は 1 月目 1 秒， 2 月目 3 秒， 3 月目 11 秒， 6 月目 16 秒， 2 年 5 月目 20 秒以上と次第に延長した。一点注視 で頭部を右から左へ回転させても視標は静止し て見えたが，頭部を左から右へ回転すると視標 が動いてしまう頭・眼の協調運動障害を示す症 状がみとめられ，それも次第に軽減したが 2 年 7 月後にも軽度ながら残存していた。なお右温 


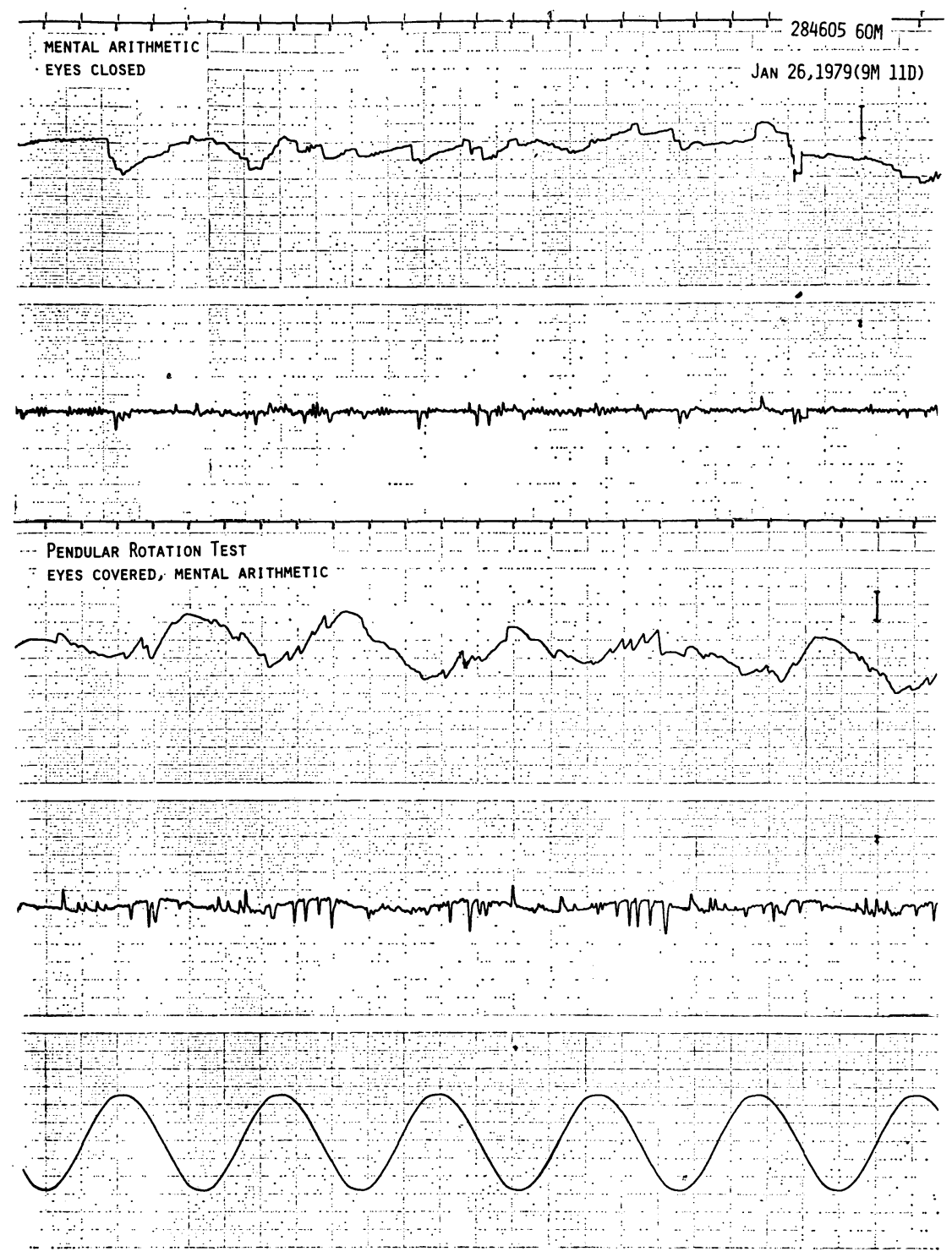

図 1 一側末梢性前庭障害例の自発眼振ならびに振子様回転眼振

症例 260 才男, 右前庭神経炎発症後 9 月 11 日目, 健側向き自発眼振と振子様回転眼 振左 DP がみとめられる.

上段閉眼暗算の ENG 水平誘導, 下段振子様回転刺激時の ENG 時定数 3 秒，0.03秒，時標 1 秒，較正 $10^{\circ} ， 20^{\circ} /$ 秒，最下段は振子様回転刺激の運 動, 周期 4.5 秒.

度反忍の低下は最後まで改善しなかった。本 例は右前庭神経炎と診断された。

〔症例 3〕No. 257800 74才男 会社役員 早朝起床時激しい回転性めまい, 嘔気, 嘔吐
が出現した。耳鳴, 難聴はなくやや風邪ぎみで あった．血圧は195/90に上昇したが 2 日後には 135/85に戻った。 4 日間めまいが持続し． 5 日 目に離床したととろ再びめまいがみられた。歩 
行時のめまいと体動摇の訴えで発症 1 月目に来 院. 聴力検査では年令変化とみなされる軽度の 高音難聴をみとめ, 平衡機能検査ではロンベル グ陽性，閉眼で30歩の足踏みが可能であったが 歩調はおそく体動摇が著しかった。温度検查で は左高度迷路機能低下を示したが注視眼振，フ レンツェル眼鏡下での非注視眼振はみられなか
った．ENG 記録では振子椂回転検査で眼振左 右差は明らかでなかったが，閉眼暗算で右向き 眼振がみとめられた。（図 2）

症例 2 と同じく疲れると体動摇感が増強しフ レンツェル眼鏡下で 5 月目から 1 年 7 月目まで の間時々右向き頭位変換眼振が観察された。 1 年 9 月目マン検査直立 5 秒，片足立ち不能であ

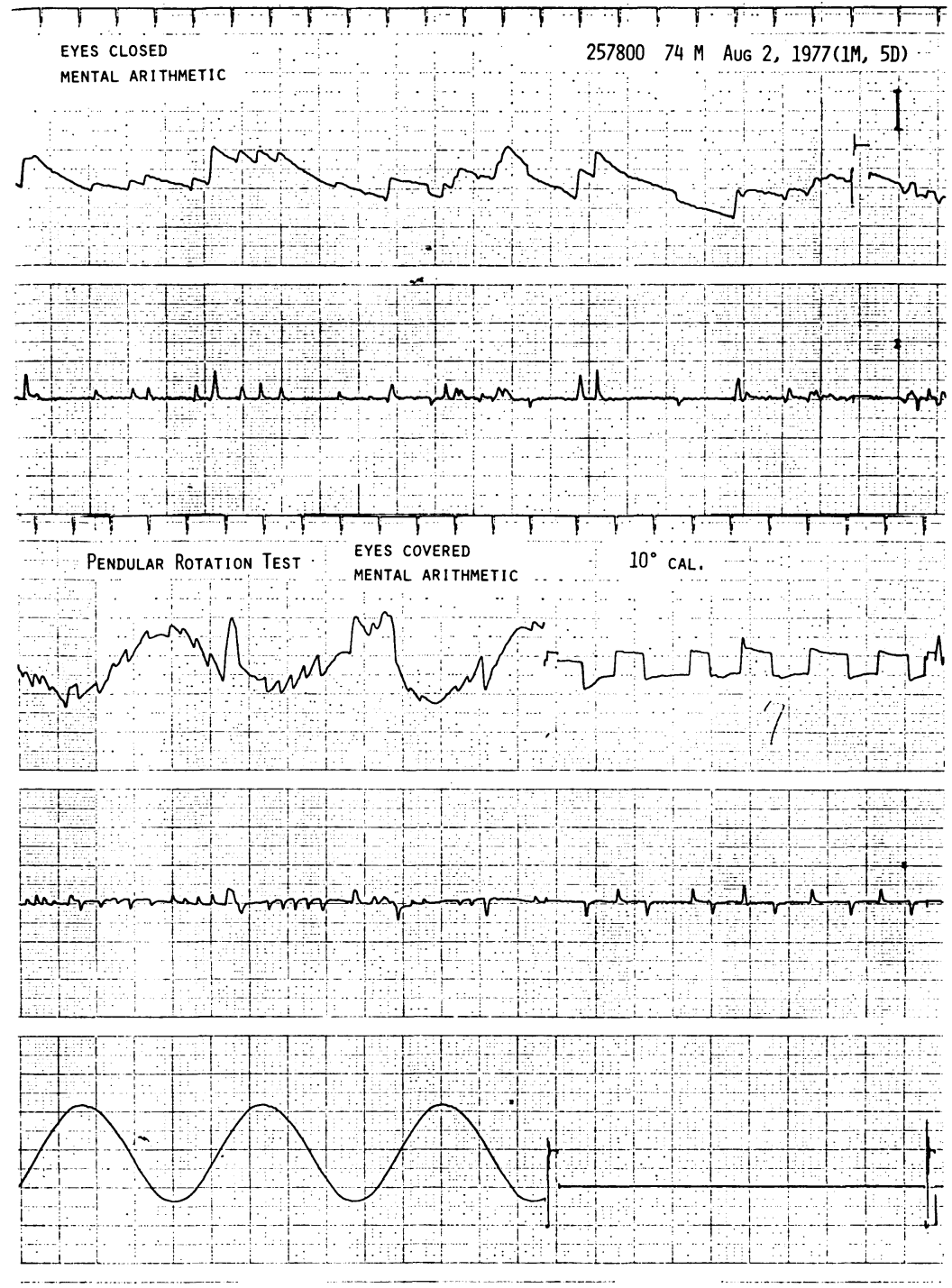

図 2 一側末梢前庭障害例の自発眼振ならびに振子様回転眼振

症例 374 才男, 左前庭神経炎, 発症後 1 月 5 日で著明な健側向き自発眼振があ るが振子様回転眼振では左右差は明らかでない。 記録条件は図1 亿同じ。 
つたが 3 年 7 月目にはマン検查 15 秒片足立ち 5 秒に恢復し足踏み検査は正常, めまい感も殆ん ぞ消失した。しかし温度検査での改善は認めら れなかった。

本例は左前庭神経炎と診断された。

\section{〔症例 4〕No. 348173 64才男}

開放性肺結核のため SM，INAH，RFP の三 者併用療法を受け，体のふらつきと難聴を自覚 したので SM は中止した。 SM は 1 日 $1 \mathrm{~g}$, 連 日投与で総量 $34.5 \mathrm{~g}$ を使用した。後頭部重感, 体動時の動摇感，夜間外出困難の訴えで， 1 年 5 月目に来院した。

来院時聴力検査で $4000 \mathrm{~Hz}, 8000 \mathrm{~Hz}$ は両側と も $60 \mathrm{~dB}$ の高音難聴がみとめられた。平衡機能

\section{考}

一側末梢性前庭障害の症状

ヒトで一側の内耳あるいは前庭一次ニューロ ンが急速に障害されると，安静時にもみられる 激しいめまい，めまいに併う嘔気，嘔吐の自律 神経症状, 頭位変化で増強するめまい感, 立直 り障害, 四肢軀幹の 偏倚, 自発眼振, 頭位眼 振, 頭位変換眼振, 温度検査での迷路機能低下 などがみられる。

Kolb（1955）は蛙で一側内耳を破壊し頭部の 傾斜を定量的に調べそれが指数亟数的に消退し
検査ではロンベルグ陰性であったがマン検査, 片足立ち検査は不能，閉眼足踏みも不能であっ た。 注視眼振，非注視眼振はみられず，温度検 査では両側高度の迷路機能低下を示した。

しかし jumbling 現象の訴えはなかった。 本例は SM 中毒による両側内耳障害と診断 された。

閉眼の立直り障害, 足踏み障害の恢復は極め て悪く温度検査の恢復はみられなかった。

しかし発症後 2 年 5 月目にはマン検査, 片足 立ち検査で閉眼にて 4 秒間起立可能となり，閉 眼足踏みは数歩可能となり僅かではあるが体の 安定感が恢復し夜間も少し歩けるようになっ た。

\section{按}

て行くことを観察した。 ヒトでみられる所見も 時間とともに改善を示してれは代償によるもの と考えられている. 症状や所見の時間経過は温 度検査での恢復がなくても，時間の対数に逆比 例して行くが，それぞれの症状によって消失に 至るまでの期間に違いがある。（図 3 ）

中枢性代償の意味

代償過程は前庭系生理の特徵の一つで多くの 基礎的研究があるが，臨床的には代償の完成を 如何にして促進させるかが急務であろう。代償

Paroxysmal Peripheral Vestibular Hypofunction

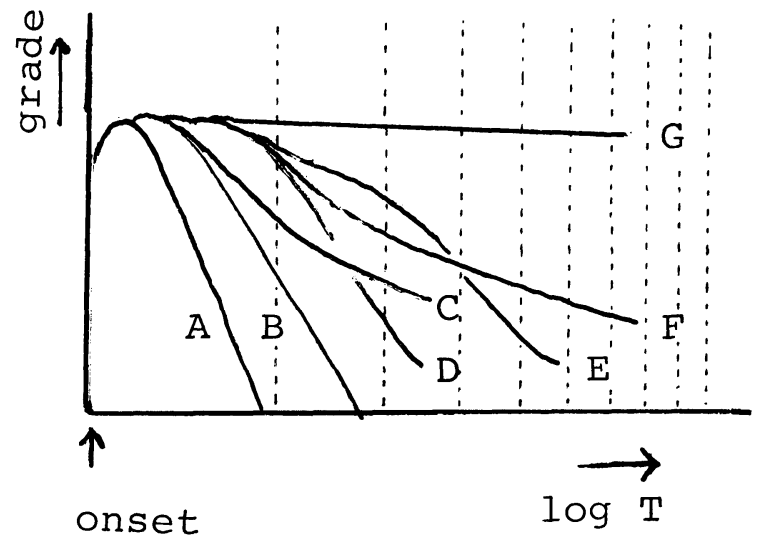
A, nausea and vomiting
$B$, vertigo at rest
$\mathrm{C}$, vertigo or dizziness under provocation
D, body sway in standing
$\mathrm{E}$, body deviation in walking
$\mathrm{F}$, spontaneous nystagmus
$\mathrm{G}$, canal paresis

図 3 突発性一側性末梢性前庭障害の症状ならびにその経時的変化子想図 横軸は時間, 縦軸は症状・検査異常所見の程度を示す. 
獲得に影響する因子には，内耳や前庭神経の障 害の起り方，その恢復の有無に関係する病理変 化, 病変の程度, 病巣の範用, 患者の年令, 生 活環境, 薬物, 手術などの治療, 訓練などがあ げられる．回転後眼振や回転後のめまいは一過 性の平衡障害と考えられる.

回転刺激を反復すると回転後眼振や回転後め まいは次第に減弱してれは反応減少 response decline（RD）現象として知られている. RD 現象は温度刺激による眼振にもみられ，その例 として回転刺激の訓練を経た熟練したダンサー やフィギャースケート選手でみられる回転後眼 振の減少があげられる，乙の現象は，前庭性誘 発反応（例えば回転後眼振）が他の知覚（例え ば視覚, 深部知覚）と矛盾する時, 前庭刺激を 反復することによって前庭性誘発反応は次第に 減弱すると総括されている。(Collins. 1974)

反復前庭刺激が内耳障害による症状改善に役 立つのではないか推定させる現象として, 初期 の自発性めまいが消退しておきあがれるように なった患者では誘発性めまいや病的眼振が比較 的早く消退してゆくてとが少くない．乙の意味 で前庭刺激を反復する訓練を治療の一つとして 積極的に利用するべきと思われるがあまり論じ られていない。

訓練が治療として有効か否かは, 他の薬物, 手術治療の効果判定と同じく代償の自然経過と の比較で検討しなければならない。

中枢性代償の機序

代償の機序について多くの基礎的研究がある (Precht 1974, Schaeffer et al 1974).

前庭神経および前庭神経核には通常安静時に 左右均等に自発放電がみられ，左右均等の骨格 筋緊張をおこし正しい姿勢がみられる.

動物で一側の内耳破壞で前庭神経核の自発放 電は健側優位となり著明な姿勢の変化, 運動時 の患側への偏倚，健側向き自発眼振が現われ， この状態は前庭性左右不均衡と呼ばれる。

前庭性左右不均衡は時間経過とともに次第に 修正され軽減する．Kornhuber（1966）はこの
修正現象のうち前庭系中枢の働きでおこるもの を代償 compensationとし，他の中枢神経系， 他の感覚器官の働きによるものを調整 adjustment と呼び両者を区別している.

中枢性代償機構で前庭神経核と深い関係にあ る小脳の役割が特に注目されている．古く Luciani (1891), Magnus（1924）は小脳除去によ って末消性前庭障害による眼振は増強するとと もに，生じた姿勢の異常は恢復しないと報告し ている (Schaeffer et al 1974).

Carpenter etal（1959）は猫で一側内耳破壊 と同時に小脳室頂核を破壊すると，内耳破壞の 症状は増強し, 且恢復が遅延するとしている。

また一側内耳破壊の症状が既に消失した猫で 室頂核を破壊すると一度獲得された代償が再び 消失することから中枢性代償での室頂核核の役 割を強調している。

Mc Cabe and Ryu（1969）は猫で内側前庭 神経からの自発放電を記録し，一側の内耳破壊 では一時的に両側の自発放電が消失し，あらか じめ小脳を除去しておくと，内耳破壞側のみの 自発放電の減少がみられると報告しているの で，小脳は急性期の前庭性左右不均衡に上る症 状をやわらげる働きもあると考えられる。

代償が完成されると前庭神経核の自発放電左 右差は消失し両側とも正常の放電頻度まで恢復 するといわれている. (Mc Cabe et al 1969, Precht 1974)

中枢性代償の時間経過

一側内耳破壊で始め患側向きに自発眼振がみ られ間もなく健側向きに変る，その後，自発眼 振は再び患側向きに变化するてともあり最終的 に消失する。

ヒトでは一側内耳障害後フレンツェル眼鏡下 での頭位眼振は数力月持続することもあり, 眼振計 ENG による検查では自発眼振は更に長 く続き年余にわたるとともあると云われている (Frenzel 1955, Lange and Kornhuber 1962). 一側内耳障害でみられる健側向き自発眼振は 内耳機能低下によっておてる. 障害直後の短時 
間にみられる患側向き眼振は前庭神経の一時的 な刺激状態を示すが，健側向き眼振の時期を経 て再び現われる患側向き眼振は，他の症状では すでに代償が完成された時期にみられることか ら Stenger 1959 はこれを恢復期眼振と呼んで いる.

我々の症例はいづれも一点注視下での左右へ の頭部回転運動と, 閉眼足踏み運動を連日負荷 させた．乙れは半規管の反復刺激と同時に，前 庭系，視覚系，深部知覚系の相互の協調を目的 としたものである. 前庭性平衡障害の恢復への 効果についてはなお今後の検討が必要である.

症例 4 をのぞいていづれも一側性急性末梢性 前庭障害である．患側向き眼振は経過中いづれ も観察されなかった。

症例 1 では発症後 7 週目にすべての検査所見 が正常となった．若年であるととと，病巣の性 質によって短期間での恢復が得られたものと思 う。他の症例はいづれも高齢で, 症例 2,3 は 一側前庭障害にもかかわらず長期間にわたっ て, 体の疲労時にめまい感が増強し, 立直り障 害と健側向き頭位眼振がフレンッェル眼鏡で観 察された。 2 例とも発症より 1 年 7 月目に健側 向き頭位変換眼振がみられた。前庭性左右不均 衡の修正は小脳の他, 大脳脳幹, 脊䯣や視覚や
深部知覚によってもおてる．中枢神経系や前庭 以外の知覚が体の疲労などの影響をうけるため 病的眼振でみられる代償不全が出没したものと 推定された。

症例 4 は両側内耳機能低下ながら jumbling 現象はみられず, 症例 2 では一側内耳機能低下 にもかかわらず発症初期にみられた。

症例 4 ではわずかながら内耳機能が残存ししか も視覚による内耳機能障害による補正が極めて 良いこと，症例 2 では健耳側より患耳側へ頭を 回転すると視標がばやけて見える訴えが示すよ うに頭と眼の協調運動がわるいととが，jumbling 現象のなし，ありに関係したものと考えら れた. 症例 2 の頭と眼の協調運動障害は次第に 改善したが 1 年 7 月後も僅かながら残存した。

前庭性左右不均衡による回転後眼振の左右差 は中枢神経活動の左右差の消失とともに消退す るといわれるように (Meyer zum Gotteberg et al 1950）我々の実施した訓練方法が，反復 前庭刺激により前庭性左右不均衡の軽減に役立 ち，また他の知覚との協調をたかめるための何 らかの働きがあったのではないかと考えてい る. 今後, 訓練の方法を確立しその効果を正し く判定出来るようにしたい.

\section{ま と め}

一側性末梢性前庭障害の 3 症例，および両側性障害の 1 例の平衡障害を比較的長期間にわたって 観察した。

いづれも一点注視時の頭部の左右回転と閉眼足踏みの運動練習を負荷し，めまい，立直り障害， 自発眼振を経時的に追跡した。

高齢の一側前庭障害 2 例は長期間にわたって健側向頭位眼振が出没し, 最長 1 年 7 月にもフレン ツェル眼鏡下で健側向頭位変換眼振がみとめられた。両側障害例で閉眼足ぶみの障害が著しいが， 2 年 5 月後には軽度であるが改善がみとめられた。

前庭性左右不均衡の代償獲得を促進させる運動訓練の工夫と実施を期待したい.

本論文の要旨は昭和56年 2 月厚生省特定疾患, 前庭機能異常調查研究班の第 2 回総会にて報告した．なお研究 費の一部は同研究班に援助を受けた。

設楽哲也教授の開講10周年を記念する. 
文

1) Carpenter, M. B., Fabrega, H. and Glinsmann, W. : Physiological deficit occuring with lesions of labyrinth and fastigialnuclei. J Neurophysiol $22: 222-2341959$.

2) Collins, W. E. : Habituation of vestibular responses with and without visual stimulation. In "vestibular system, part 2: psychophysics, applied aspects and general interpretations" edit. by Kornhuber, H. H. Berlin, Springer, p. 369-388 1974.

3) Erenzel, H. : Spontan- und Provokationsnystagmus als Krankheitssymptom. Berlin, Springer 1955.

4) Kolb, G. : Untersuchungen über zentrale Kompensation und Kompensationsbewegungen einseitige entstateter Försche. $Z$ vergl Physiol $37:$ 135-160 1955.

5) Kornhuber, H. H. : Physiologie und Klinik des zentral vestibulären Systems (Blick-und Stutzmorik). Hals-, Nasen-, Ohrenheilk. Vol III pt3, p. 2150-2351 Stuttgart George Thieme 1966 .

6) Lange, G., Kornhuber, H. H. : Zur Bedeutung peripher- und zentral-vestibulärer Störungen nach Kopftraumen. Arch Ohr.-Nas.-,

\section{献}

u. Kehlk.-Heilk. $179:$ 366-385 1962.

7) Mc Cabe, B. F., Ryu, J. H. : Experiments on vestibular compensation. Laryngoscope (St. Louis) $79:$ 1728-1736 1969.

8) Meyer zum Gottesberg, A., Maurer, W.: Das Ewald'sche Gesetz. Z Laryng Rhinol 29 : 532 -5401950 .

9) Precht, W.: Characteristics of vestibular neurons after acute and chronic labyrinthine destruction. In"vestibular system. part 2: psychophysics, applied aspects and general interpretations." edit. by Kornhuber, H. H. Berlin, Springer, p. 451-462 1974.

10) Schaeffer, K. P., Meyer, D. L. : Compensation of vestibular lesions. In "vestibular system. part 2: psychophysics, applied aspects and general interpretations." edit. by Kornhuber, H. H. Berlin, Springer, p. 463 4901974.

11) Stenger, H. H. : Erholungsnystagmus nach einseitigen Vestibularisausfall, ein dem Bechterewnystagmus verwandter Vergang. Arch Ohr.-Nas.-u. Kehlk.-Heilk. 175 : 545-549 1959 .

$\left(\begin{array}{l}\text { 別刷請求先 : 德増 厚二 } \\ \text { T228 相模原市麻溝台 } 1 \\ \text { 北里大学 医学部 耳鼻咽喉科学教室 }\end{array}\right)$ 